\title{
KETIDAKEFEKTIFAN KALIMAT PADA SURAT DINAS TINGKAT DESA SE-KECAMATAN DARMA KABUPATEN KUNINGAN DAN ANCANGAN POLA PEMBINAANNYA
}

\author{
Ahmad Dedi Mutiadi, Ifah Hanifah, Siti Ikasari \\ Pendidikan Bahasa dan Sastra Indonesia \\ Fakultas Keguruan dan Ilmu Pendidikan Universitas Kuningan
}

\begin{abstract}
Abstrak
Penelitian ini berjudul Ketidakefektifan Kalimat pada Surat Dinas Tingkat Desa Kecamatan Darma Kabupaten Kuningan dan Ancangan Pola Pembinaannya. Tujuan dari penelitian ini adalah untuk mengetahui ketidakefektifan kalimat pada surat dinas yang dibuat oleh staf administrasi Desa yang berada di lingkungan Kecamatan Darma serta menghasilkan ancangan pola pembinaan bahasa Indonesia berdasarkan analisis kesalahan kalimat pada surat dinas. Pendekatan dan metode penelitian yang digunakan adalah pendekatan kualitatif, dengan metode deksriptif kualitatif. Dari penelitian ini sudah terkumpul 19 surat surat dinas dan hasil analisisnya adalah sebagai berikut. (1) Ketidakefektifan kalimat pada surat dinas pemerintahan Desa Kecamatan Darma Kabupaten Kuningan banyak surat yang menggunakan kalimat yang tidak efektif. Misalnya, kalimatnya terlalu panjang, banyak menggunakan kata-kata yang tidak diperlukan, dan ketidakjelasan subjek dan predikat, (2) Berdasarkan analisis ketidaefektifan kalimat pada surat dinas, maka dibentuk ancangan pola pembinaan bahasa dalam bentuk rancangan pelaksaan pembinaan bahasa. Materi yang akan dibinakan adalah pilihan kata, penggunaan kalimat, dan sistematika. Adapaun metodenya adalah dengan praktik langsung yang dikemas dalam bentuk workshop. Sementara itu, evaluasinya akan dilaksanakan melalui proses paraktik langsung pembuatan surat dinas.
\end{abstract}

Kata kunci : Analisis Kesalahan Berbahasa, ketidakefektifan kalimat, Surat Dinas, Ancangan Pembinaan Bahasa 


\section{PENDAHULUAN}

Bahasa Indonesia mempunyai dua kedudukan sebagai bahasa nasional dan bahasa negara. Bahasa nasional bersumber pada sumpah pemuda dan merupakan bagian jati diri bangsa, keberadaannya membutuhkan perjuanan Panjang peristiwa sejarah, yaitu "sumpah pemuda" yang dicetuskan pada tanggal 28 oktober 1928 meresmikan Bahasa Indonesia sebagai bahasa nasional. Bahasa Negara bersumber pada UU nomor 24 tahun 2009 yang isinya tentang Bendera, Bahasa, Lambang Negara, dan lagu kebangsaan.

Sebagai bahasa nasional, Bahasa Indonesia memiliki beberapa fungsi antara lain sebagai; a) lambang kebanggaan nasional, b) lambang identitas nasional, c) alat pemersatu berbagai masyarakat yang berbeda-beda latar sosial, latar budaya dan bahasa, d) alat perhubungan antar budaya dan antar daerah. Sebagai bahasa negara Bahasa Indonesia memiliki beberapa fungsi antara lain sebagai ; a) bahasa resmi kenegaraan b) bahasa pengantar di lembaga pendidikan c) Bahasa resmi dalam perhubungan tingkat nasional untuk pembangunan dan pemerintahan, d) bahasa resmi dalam pengembangan kebudayaan nasional, ilmu pengetahuan dan teknologi modern. (Halim dalam Setyawati, $2013: 1-2)$.
Sesuai dengan fungsi bahasa tersebut, maka tidak mengherankan jika Bahasa Indonesia dijadikan sebagai alat untuk berkomunikasi diberbagai keperluan sesuai dengan situasi dan kondisi. Fungsi Bahasa Indonesia sebagai bahasa negara digunakan untuk penulisan laporan penelitian, penulisan makalah, skripsi, tesis, disertasi, dokumen kenegaraan, dan surat menyurat resmi yang sifatnya resmi. Karena bersifat resmi maka dalam penulisannyapun harus menggunakan Bahasa Indonesia yang baik dan benar, serta kalimat yang efektif sesuai dengan kaidah kebahasaan agar pesan di dalamnya dapat dipahami dan dimengerti oleh pembaca, salah satunya surat menyurat si instansi pemerintahan.

Surat-menyurat di lembaga pemerintahan merupakan kegiatan seharihari, khususnya di bidang administrasi. Lewat surat tersebut instansi pemerintah saling memberikan informasi tentang suatu hal yang menyangkut kedinasan.

Surat dinas adalah surat yang berisi persoalan kedinasan atau administrasi pemerintah, surat dinas dibuat hanya oleh lembaga instansi resmi dan surat tersebut dapat dikirimkan pada instansi yang memiliki hubungan dengan instansi tersebut. Karena sifatnya resmi surat dinas harus menggunakan struktur kalimat yang 
baik dan benar sesuai dengan kaidah kebahasaan. Surat dinas adalah surat yang dikirim oleh kantor pemerintah.(Soedjito dan Solchan, 2004 :14).

Dalam hal ini penulis ingin mengetahui kesalahan berbahasa Indonesia pada surat dinas, serta menganalisis kesalahannya pada tataran Sintaksis. Hal itu dilakukan karena berdasarkan hasil observasi yang dilakukan penulis ke instansi pemerintahan mengenai surat dinas yang dikeluarkan oleh lembaga tersebut, ditemukan bahwa staf administrasi atau pembuat surat kurang memahami dalam menuliskan kalimat bahasa Indonesia yang efektif. Selain itu, adanya informasi bahwa staf administrasi kesulitan dalam menuliskan kosa kata bahasa Indonesia dengan benar dan terkadang pula mengambil jalan pintas dengan mengunduh contoh surat dari internet kemudian direvisi sesuai kebutuhannya.

Berdasarkan masalah di atas penulis mendeskripsikan kesalahan dalam penulisan surat dinas. Penulis mengambil objek yaitu surat dinas yang dikeluarkan oleh lembaga instansi pemerintahan desa yang ada di Kecamatan Darma Kabupaten Kuningan. Selain menganalisis dan mendeskripsikan, penulis pula membuat rencana pembinaan Bahasa Indonesia tentang penulisan surat dinas dengan menggunakan bahasa yang baku serta penulisan kalimat yang efektif berdasarkan kesalahan berbahasa yang terdapat pada surat dinas tingkat Desa seKecamatan Darma Kabupaten Kuningan Jawa Barat.

\section{METODOLOGI PENELITIAN}

Metode penlitian yang digunakan peniliti adalah penelitian Deskriptif kualitatif karena penelitian ini bersifat analisis. Karena dalam penelitian ini lebih banyak menggunakan bentuk kata daripada angka. Penelitian ini termasuk dalam jenis Penelitian Deskriptif Analisis konten atau dokumen. Analisis konten atau dokumen ditujukan untuk menganalisis dokumen resmi, dan kebahasaannya terjamin baik.

\section{HASIL PENELITIAN}

Objek dalam penelitian ini adalah surat dinas yang ada di lingkungan Desa Kecamatan Darma Kabupaten Kuningan, keseluruhan Kecamatan Darma ada 19 Desa namun yang bersedia memberikan surat dinasnya hanya 13 Desa, dan 6 Desa lainnya tidak bersedia memberikan surat dinas dengan alasan yang beragam. 


\section{1) Hasil Analisis Ketidakefektifan} kalimat pada Surat Dinas tingkat desa kecamatan Darma Kabupaten

\section{Kuningan}

Setelah data terkumpul, langkah pertama yang dilakukan adalah melakukan analisis kesalahan berbahasa pada surat dinas keluar dari Desa tersebut. Analisis kesalahan berbahasa itu mencakup analisis kesalahan kalimat yang dilihat dari tataran keefektifan yang mencakup unsur Kelengkapan strukturkesepadanan, keparalelan, kehematan kata, kepaduan gagasan, kecermatan penalaran, dan ketegasan. Setelah dianalisis.

Untuk kategori ini banyak didapati kesalahan surat dinas terutama dalam penulisan kalimat efektif. Banyak surat yang menggunakan kalimat yang tidak efektif. Misalnya, kalimatnya terlalu panjang, banyak menggunakan kata-kata yang tidak diperlukan, dan ketidakjelasan subjek dan predikat.

\section{2) Langkah Rencana Pelaksanaa}

\section{Pembinaan Penulisan Surat Dinas}

\section{Tingkat Desa Kecamatan Darma}

Berdasarkan analisis kesalahan pada surat dinas, maka disusun langkah dan rencana pelaksanan pembinaan surat dinas sebagai berikut.
Berikut adalah Langkah pembinaan penulisan surat dinas yang telah disusun.

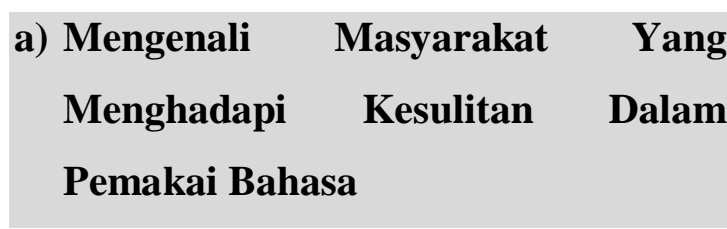

Mengenali masyarakat atau pegawai yang menjadi target pembinaan, yaitu pegawai/staf administrasi tingkat Desa yang berada di lingkungan Kecamatan Darma Kabupaten Kuningan.

\section{b) Tujuan Pembinaan Penyusunan Surat Dinas}

Setelah mengikuti pembinaan penyusunan surat dinas, para staf administrasi atau pembuat sura $t$ dinas di Desa Kecamatan Darma dapat membuat surat dinas dengan baik dan benar sesuai aturan yang telah ditentukan baik dari pilihan kata, pemilihan kalimat, dan sistematikanya.

\section{c) Deskripsi Materi Pembinaansurat Dinas \\ Penyususnan surat merupakan} kegiatan yang biasa dilakukan oleh para staf administrasi atau sekretaris atau para pembuat surat di lembaga lembaga pemerintahan. Setiap ada kegiatan selalu membuat surat sebagai bukti tertulis bahwa kegiatan yang dilakukan merupakan kegiatan resmi, oleh karena itu surat yang dibuat pun surat resmi. Ciri 
dari surat resmi ada aturanaturan dalam penyusunan surat yang harus diikuti oleh para staf administrasi diantaranya aturan penyusunan kata dan kalimat bahkan sistematika. Surat resmi yang dibuat oleh suatu lembaga ditujukan kepada lembaga lain ataupun kepada perorangan dengan dengan aturan yang telah ditentukan dinamakan surat dinas.

\section{d) Pendekatan}

Selama mengikuti pembinaan penyusunan surat dinas ini para peserta diwajibkan :

(1) Metode workshop

(2) Tugas Praktik menyususn surat dinas

(3) Medianya yaitu LCD

\section{e) Evaluasi}

Evaluasi pembinaan penyusunan surat dinas yaitu :

Dalam kegiatan evaluasi, masingmasing pegawai/staf administrasi menyerahkan arsip surat yang dikeluarkan selama satu bulan setelah penyuluhan atau worshop dilaksanakan untuk di analisis oleh penyuluh bahasa dalam kurun waktu 3 bulan. Hasil analisis surat tersebut.

\section{SIMPULAN}

Berdasarkan hasil analisis dan pengolahan data penelitian ini, maka dapat disimpulkan hal-hal berikut.

1) Dari hasil analisis surat dinas di lingkungan Desa Kecamatan Darma Kabupaten Kuningan Jawa Barat terdapat kesalahan berbahasa dalam bentuk keefektifan kalimat sebagai berikut.

a) Ketidakjelasan subjek dan predikat yang terdapat pada surat dinas tingkat Desa Kecamatan Darma sehingga kalimat menjadi tidak efektif.

b) Penggunaan kata-kata yang tidak perlu atau boros pada surat dinas tingkat Desa Kecamatan Darma sehingga kalimat menjadi rancu dan tidak efektif.

c) Dari segi kesepadanan pada surat dinas tingkat Desa Kecamatan Darma sudah dikatakan efektif.

d) Ketidakparalelan dalam penggunaan kalimat pada surat dinas tingkat Desa Kecamatan Darma sehingga kalimat tersebut menjadi tidak efektif.

e) Ketidakpaduan ide pokok gagasan pada surat dinas tingkat Desa Kecamatan Darma sehingga kalimat menjadi tidak efektif. 
f) Dari segi kecermatan penalaran pada surat dinas tingkat Desa Kecamatan

Darma sudah dikatakan efektif sehingga dapat dipahami oleh para penerima surat.

g) Dari segi ketegasan makna pada surat dinas tingkat Desa Kecamatan Darma dikatakan efektif.

2) Berdasarkan analisis ketidakefektifan berbahasa pada surat dinas di lingkungan Desa Kecamatan Darma Kabupaten Kuningan, pola pembinaannya dengan kegiatan workshop. Adapun rincian pola pembinaannya sebagai berikut.

(a) Sasaran yang ditujunya adalah pegawai/staf administrasi Desa Kecamatan Darma Kabupaten Kuningan.

(b) Waktunya disesuaikan dengan pelaksanaan penyuluhan

(c) Tempat penyuluhan d Aula Kantor Kecamatan Darma

(d) Tujuan penyuluhan sebagai berikut.

1. Meningkatkan wawasan kebahasaan dalam penggunaan kalimat yang efektif.

2. Meningkatkan sikap positif tentang penggunaan Bahasa Indonesia yang benar pada penulisan surat dinas.

3. Menerapkan pengetahuan mengenai penulisan kalimat dengan benar yang diperoleh dalam kegiatan penyuluhan ke dalam kegiatan sehari-hari di lingkungan kerjanya.

4. Menulis surat dinas dengan menggunakan Bahasa Indonesia yang benar sesuai dengan tata Bahasa baku Bahasa Indonesia.

(e) Materinya tentang kesalahan berbahasa mengenai aturan ejaan, penyusunan kata dan kalimat bahkan sistematika dalam membuat surat dinas tingkat Desa Kecamatan Darma Kabupaten Kuningan.

(f) Evaluasi yang dilakukan yaitu dengan menyusun surat dinas menggunakan skala penilaian yang diberikan oleh Pemateri.

(g) Media yang digunakan yaitu LCD, power point, dan surat dinas.

(h) Sumber penyuluhan yaitu Buku Sintaksis (Abdul Chaer), Surat Menyurat resmi Bahasa Indonesia (Sochlan dan Soedjito), Cermat Berbahasa Indonesia (Zaenal Arifin), Surat Menyurat dan Menulis Surat Dinas dengan Benar (E.Kosasih). 


\section{DAFTAR PUSTAKA}

Ahyadi, Didi. 2011. Linguistik Umum.

Kuningan:Universitas Kuningan.

Arifin, Zaenal E dan Amran Tasai. 2008. Cermat Berbahasa Indonesia. Jakarta : Akademika Pressindo.

Chaer, Abdul. 2014.Linguistik Umum. Jakarta: PT Rineka Cipta.

Chaer, Abdul. 2009. Pengantar Sintaksis Bahasa Indonesia. Jakarta: PT Rineka Cipta.

Jauhari, Heri. 2010. Pedoman Penulisan Karya Ilmiah. Bandung : CV. Pustaka Setia.

Kosasih, E dan Sutari, Ice. 2003. Surat Menyurat dan Menulis Surat Dinas dengan Benar. Bandung : CV Yrama Widya.

Kosasih dan Wawan Hermawan. 2012. Bahasa Indonesia Berbasis Penulisan Karya Ilmiah dan Jurnal. Bandung : CV. Thursina.

Hanifah, Ifah dan Sun Suntini. 2017. Peyusunan Ancangan Pola Pembinaan Bahasa Indonesia Berdasarkan Analisis Kesalahan Berbahasa Pada Surat Dinas Lembaga Pemerintahan Di Kabupaten Kuningan.

Jurnal Visipena. Vol.8 (1). Januari. Hal. 33-45.

Heryadi, Dedi. 2009. Pengembangan dan Pembinaan Bahasa Indonesia. Tasikmalaya : Univeristas Siliwangi.

Heryadi, Dedi. 2010. Metode Penelitian Bahasa. Bandung : PusbillBandung.
Ramlan, M. 1987. sintaksis. Yogyakarta: C.V. KARYONO.

Setyawati, Nanik. 2013. Analisis Kesalahan Berbahasa Indonesia Teori Dan Praktik.Yogyakarta : Yuma Pustaka.

Sugiyono. 2012. Metode Penelitisn Kuantitatif, Kualitatif dan $R \& D$. Bandung : C.V. Alfabeta.

Surakarta.Purwandari, Heni Setya, dkk. 2014. Analisis kesalahan

berbahasa Indonesia Pada Surat Dinas Kantor Desa Jladri.

BASASTRA Jurnal Penelitian Bahasa, Sastra Indonesia, Vol.1, (3), 478489. [Online]. Tersedia di :

http:jurnal.fkip.uns.ac.id/indexphp/bhs_in donesia/article/4045

[27 Ferbruari 2018].

Soedjito dan Solchan. 2004. Surat Menyurat Resmi Bahasa Indonesia. Bandung : PT Remaja Rosdakarya.

Tasai, Amran dan Abdul Rozak Zaidan. 2008. Pembinaan dan Pengembangan Bahasa Indonesia. Jakarta : Universitas Terbuka.

Tauandy, Lutfi Aji. 2013. Analisis kesalahan berbahasa pada penulisan surat dinas .Surakarta : Universitas Muhamadiyah.

Yulianto, Bambang dan Maria Mintowati. (2015). Analisis Kesalahan Berbahasa.

Jakarta : Univeristas 